\title{
The Acute Phase Protein Hepcidin Is Cytotoxic to Human and Mouse Myeloma Cells
}

\author{
DAVID M. CONRAD ${ }^{1,2,3}$, ASHLEY L. HILCHIE ${ }^{4}$, KATELYN A.M. MCMILLAN ${ }^{4}$, \\ ROBERT S. LIWSKI ${ }^{1,2,3}$, DAVID W. HOSKIN ${ }^{2,3,5}$ and MELANIE R. POWER COOMBS ${ }^{2,4}$ \\ ${ }^{1}$ Department of Pathology \& Laboratory Medicine, Division of Hematopathology, \\ Queen Elizabeth II Health Sciences Centre, Halifax, NS, Canada; \\ ${ }^{2}$ Department of Pathology, Dalhousie University, Halifax, NS, Canada; \\ ${ }^{3}$ Department of Microbiology and Immunology, Dalhousie University, Halifax, NS, Canada; \\ ${ }^{4}$ Biology Department, Acadia University, Wolfville, NS, Canada; \\ ${ }^{5}$ Department of Surgery, Dalhousie University, Halifax, NS, Canada
}

\begin{abstract}
Background/Aim: Hepcidin is a cationic acute phase reactant synthesized by the liver. It has bactericidal properties and is a major regulator of iron homeostasis. Cationic antimicrobial peptides represent an innate antimicrobial defense system. We hypothesized that, like other cationic antimicrobial peptides, hepcidin is cytotoxic to cancer cells. Materials and Methods: The cytotoxicity of human hepcidin against myeloma cells was assessed by 3-[4,5-dimethylthiazol-2-yl]-2,5-diphenyl tetrazolium bromide (MTT) and DNA fragmentation assays. Plasma membrane damage was quantified by propidium iodide (PI) staining. Cell membrane changes were visualized by scanning electron microscopy. Results: Hepcidin impaired myeloma cell survival and induced DNA fragmentation. PI staining and scanning electron microscopy revealed hepcidininduced disruption of the plasma membrane. Conclusion: Human hepcidin is an anti-cancer peptide that induces myeloma cell lysis, and therefore may play a role in innate anticancer immunity. To our knowledge, this is the first biological function ascribed to human hepcidin that is not related to its antimicrobial and iron-regulatory properties.
\end{abstract}

Multiple myeloma is the second leading cause of death from hematological malignancies (1). Despite ongoing research and development in cancer therapeutics, multiple myeloma largely remains an incurable disease $(2,3)$. By virtue of its

This article is freely accessible online.

Correspondence to: Melanie Coombs, Ph.D., Biology Department, 33 Westwood Ave., Wolfville, NS B4P 2R6, Canada. Tel: +1 9025851162, e-mail: melanie.coombs@acadiau.ca

Key Words: Myeloma, hepcidin, DNA fragmentation, membrane damage, cell death. slow growth, myeloma is refractory to chemotherapy agents that are most effective against rapidly dividing cancer cells (4). Newer therapies for myeloma, such as daratumumab, are thought to kill myeloma cells by multiple mechanisms, including cell lysis (5-7).

Cationic antimicrobial peptides represent an innate antimicrobial defense system that exerts immunomodulatory effects and antimicrobial activity against both Gram-negative and Gram-positive bacteria, as well as fungi, protozoa, and viruses (8-13). Recent studies suggest that some cationic antimicrobial peptides contribute to innate anticancer immunity and are, thus, termed anticancer peptides (ACPs). ACPs are able to kill cancer cells while leaving normal cells virtually unaffected (14-16). This apparent selectivity towards cancer cells is thought to be due to cell membrane charge differences between neoplastic and normal cells (17). The positive charge of ACPs allows them to interact with the negatively charged cytoplasmic membrane of cancer cells, regardless of their rate of cellular division (16). The mechanisms by which ACPs subsequently mediate cancer cell death include loss of cell membrane integrity and/or disruption of the mitochondrial membrane with release of cytochrome $\mathrm{C}$, accumulation of reactive oxygen species, and induction of apoptosis $(15,16,18-21)$. Importantly, ACPs are equally effective at killing rapidly and slowly growing cancers, in addition to chemoresistant cancer cells $(15,22,23)$.

Hepcidin is a 25 -amino acid cationic antimicrobial peptide produced by hepatocytes as part of the acute phase response (24). Hepcidin is involved in iron homeostasis; its expression is increased during inflammation, resulting in anemia of chronic disease (25). In addition, hepcidin negatively regulates iron absorption in the small bowel, transplacental iron transport, and the release of iron from macrophages. These effects are mediated by hepcidin's negative regulation of ferroportin, the major iron exporter of vertebrates (26). Transcription of the hepcidin gene is up-regulated in 
response to several stimuli, including proinflammatory cytokines (27-29), and serum levels of hepcidin increase after lipopolysaccharide injection into healthy volunteers (30). Increased concentrations of circulating hepcidin have been reported in anemia in the context of inflammatory states, likely accounting for the sequestration of iron in macrophages that is seen in these conditions $(25,31)$. Elevated serum hepcidin levels have been observed in the setting of numerous cancers, including plasma cell myeloma (32). Interestingly, patients with low levels of hepcidin, as occurs in hereditary hemochromatosis, thalassemia, and iron deficiency anemia, have an increased risk of cancer (33-36).

Plasma cell myeloma is an indolent cancer that is generally refractory to conventional chemotherapy and without cure $(2,3)$. Little is known about the effect of ACPs on myeloma cells, although a previous study from our lab shows that myeloma cell lines are sensitive to the cytotoxic effects of at least some ACPs (14). We hypothesized that human hepcidin would be cytotoxic to myeloma cells in vitro and therefore act as an ACP. We believe that elevated concentrations of hepcidin in the context of cancer may reflect a previously unappreciated aspect of innate anticancer immunity in humans (37).

\section{Materials and Methods}

Hepcidin. Hepcidin-20 was purchased from American Peptide Company (Sunnyvale, CA, USA). This 20 -amino acid peptide isoform of human hepcidin, which lacks the ability to regulate iron (38), was used in this study so that only iron-independent effects of hepcidin would be observed. Concentrated stock solutions of hepcidin dissolved in phosphate-buffered saline (PBS; Sigma-Aldrich Canada, Oakville, ON, Canada) were aliquoted and stored at $-80^{\circ} \mathrm{C}$.

Cell culture and conditions. Human U266 myeloma cells were kindly provided by Dr. Tony Reiman (Saint John Regional Hospital, Saint John, NB, Canada), mouse HOPC myeloma cells were purchased from the American Type Culture Collection (Manassas, VA, USA). Melphalan-resistant U266 cells were passaged weekly in $10 \mu \mathrm{M}$ melphalan (Sigma-Aldrich Canada). All cell lines were maintained at $37^{\circ} \mathrm{C}$ in a $5 \% \mathrm{CO}_{2}$ humidified atmosphere in RPMI1640 medium (Sigma-Aldrich Canada) supplemented with 5\% heatinactivated fetal bovine serum (FBS), $5 \mathrm{mM}$ HEPES [4-(2hydroxyethyl)-1-piperazineethanesulfonic acid] ( $\mathrm{pH} 7.4), 100 \mathrm{U} / \mathrm{ml}$ penicillin, and $100 \mu \mathrm{g} / \mathrm{ml}$ streptomycin (Invitrogen, Burlington, ON, Canada). Peptide experiments were conducted with complete medium containing $0.5 \%$ FBS.

Cell viability assay. Cell viability assays were performed to assess the effect of human hepcidin against mouse and human myeloma cells by measuring metabolic activity. U266 cells or HOPC cells were seeded in quadruplicate at $5 \times 10^{4}$ cells/well into 96 -well flat-bottomed tissue culture plates (Sarstedt, St. Leonard, QC, Canada) and treated with medium/PBS vehicle alone or human hepcidin at 25,50 , and $100 \mu \mathrm{M}$ for $24 \mathrm{~h}$. In other experiments, melphalan-resistant U266 cells were cultured in the absence or presence of $100 \mu \mathrm{M}$ of human hepcidin for $24 \mathrm{~h}$. For the last $2 \mathrm{~h}$ of culture, $0.1 \mathrm{mg}$ 3-(4,5-dimethylthiazol-2- yl)2,5-diphenyltetrazolium bromide (MTT) was added to cell cultures. Formazan crystals were solubilized in $100 \mu \mathrm{l} /$ well dimethyl sulfoxide (DMSO) and absorbance $(490 \mathrm{~nm})$ was measured using a Bio-Tek microplate reader (Bio-Tek Instruments, Winooski, VT, USA). Average percent metabolic activity was calculated by the formula: (optical density of treatment/optical density of no treatment control) $\times 100$ as previously described (15).

Propidium iodide assay. Propidium iodide (PI) uptake was measured by flow cytometry to assess cell membrane damage induced by hepcidin. U266 or HOPC cells were treated with vehicle or $100 \mu \mathrm{M}$ hepcidin for $30 \mathrm{~min}$ and $2 \mathrm{~h}$. Cells were then stained with $5 \mu \mathrm{g} / \mathrm{ml}$ PI (Invitrogen) for $5 \mathrm{~min}$, washed, and PI uptake was quantified with a FACSCalibur flow cytometer (BD Biosciences, San Jose, CA, USA).

DNA fragmentation assay. The effect of hepcidin on the integrity of DNA in U266 and HOPC cells was determined using a DNAfragmentation assay (39). Cells were labelled with $0.25 \mu \mathrm{Ci}$ of tritiated thymidine $\left(\left[{ }^{3} \mathrm{H}\right]-\mathrm{TdR}\right.$; MP Biomedicals LLC, Santa Ana, CA, USA), washed, and seeded in quadruplicate at $5 \times 10^{4}$ cells/well into 96-well U-bottom cell culture plates. Cells were cultured in the absence or presence of $100 \mu \mathrm{M}$ of hepcidin for 2, 6, and $24 \mathrm{~h}$. Cells were then harvested onto glass fiber mats using a Skatron multiple sample harvester and $\left[{ }^{3} \mathrm{H}\right]-\mathrm{TdR}$ recovery was determined by liquid scintillation counting. Data are expressed as \% DNA fragmentation, which was determined as follows:

$\%$ DNA fragmentation for treated cells $=(1-[\mathrm{cpm}$ from treated cells $] /[\mathrm{cpm}$ from PBS-treated cells] $) \times 100$.

Scanning electron microscopy. Scanning electron microscopy was used to assess U266 and HOPC cell membrane changes following exposure to hepcidin. Cells were grown on sterile circular poly-Llysine-coated coverslips with vehicle (PBS) or $100 \mu \mathrm{M}$ of hepcidin for $30 \mathrm{~min}$ and $2 \mathrm{~h}$. Cells were then fixed with glutaraldehyde $(2.5 \%$ [v/v] in $0.1 \mathrm{M}$ sodium cacodylate), washed with $0.1 \mathrm{M}$ sodium cacodylate, fixed with osmium tetroxide $(1 \%[\mathrm{w} / \mathrm{v}]$ in $0.1 \mathrm{M}$ sodium cacodylate) for $30 \mathrm{~min}$, washed, and dehydrated in increasing concentrations of ethanol. Prepared cells were dried to their critical point using a Polaron E3000 Critical Point Dryer (Quorum Technologies, Guelph, ON, Canada), mounted, and coated with gold using a Polaron SC7620 Mini Sputter Coater (Quorum Technologies). Cells were viewed at 500x, $7000 \times$ and $40000 \times$ magnification using a Hitachi S4700 scanning electron microscope (Hitachi High Technologies, Rexdale, ON, Canada).

Statistical analysis. GraphPad Prism 7.0 was used to perform one-way ANOVA with Tukey post-test on data from at least three independent experiments. Statistical significance was identified as $p<0.05$.

\section{Results}

Hepcidin reduces the metabolic activity of myeloma cells. MTT assays were used to determine the effect of hepcidin on myeloma cell viability, as indicated by altered metabolic activity. Figure 1 shows that hepcidin reduced the metabolic activity of human U266 (Figure 1A) and mouse HOPC (Figure 1B) myeloma cell lines in a concentration-dependent manner. 
A

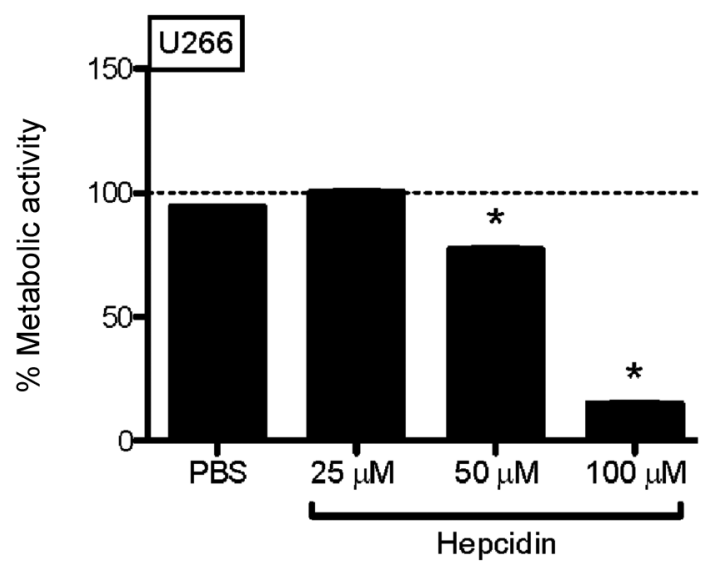

B

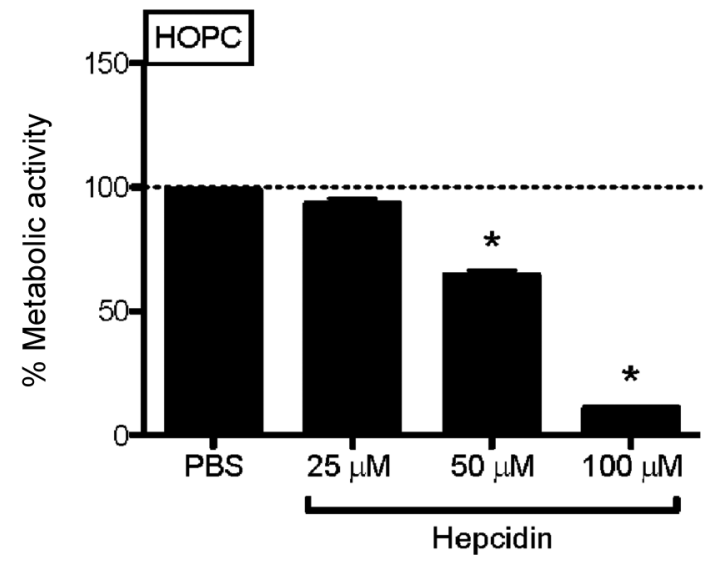

Figure 1. Human hepcidin causes concentration-dependent reduction in human and mouse myeloma cell viability. (A) Human U266 and (B) mouse HOPC myeloma cells were cultured in the presence of medium alone, vehicle (PBS), or the indicated concentrations of human hepcidin for 24 , after which changes in metabolic activity were determined by MTT assay. Data are presented as the average \% metabolic activity (optical density of treatment relative to medium control $\times 100) \pm S E M, n=4 ; * p<0.05$ determined by one-way ANOVA and Tukey post-test.

To our knowledge, this is the first report of human hepcidin possessing anticancer properties. Interestingly, PC3 human prostate and HT-29 human colorectal cancer cells were not killed by hepcidin (data not shown). Melphalan is an alkylating chemotherapeutic agent that is used to treat plasma cell myeloma (40). However, current chemotherapeutic drugs have limited effectiveness against plasma cell myeloma, in part due to their inability to kill multidrug-resistant cancer cells $(2,3)$. A $100 \mu \mathrm{M}$ concentration of hepcidin was cytotoxic for melphalan-resistant U266 cells (vehicle, 93 $\pm 4 \%$ metabolic activity relative to the medium control; hepcidin, $45 \pm 10 \%$ metabolic activity relative to the medium control, $p<0.05 ; \mathrm{n}=3$ ).

Hepcidin causes substantial cell membrane damage to myeloma cells. Flow cytometric analysis of cellular PI uptake was used to measure myeloma cell plasma membrane damage following exposure to hepcidin. As shown in Figure 2, hepcidin caused substantial PI uptake in both human U266 (Figure 2A and B) and mouse HOPC (Figure 2C and D) myeloma cells. Representative histograms of fluorescence are shown in Figure 2A and C, whereas average fluorescence is shown in Figure 2B and D. Scanning electron microscopy was used to visualize cell membrane changes in the presence of hepcidin. The resulting images confirmed that exposure to hepcidin damaged the cell membrane of human (Figure 3A) and mouse (Figure 3B) myeloma cells by causing extensive pore formation.

Hepcidin triggers DNA fragmentation in myeloma cells. Figure 4 shows that after only $2 \mathrm{~h}$, exposure to hepcidin caused human U266 (Figure 4A) and mouse HOPC (Figure 4B) myeloma cells to experience extensive DNA fragmentation. By $24 \mathrm{~h}$, DNA fragmentation was almost complete, indicating a timedependent effect.

\section{Discussion}

The acute phase protein hepcidin possesses antimicrobial properties afforded by its overall positive charge. Numerous antimicrobial peptides are also endowed with anticancer properties imparted by their positive charge, which allows them to preferentially interact with negatively charged cancer cell membranes. Our study provides the first evidence that human hepcidin kills myeloma cells, and thus also behaves as an anticancer peptide (ACP). The cytotoxic effect of hepcidin was both concentration- and timedependent, mediated by its ability to induce pore formation in the myeloma cell plasma membrane (Figures 2 and 3). This lytic mechanism of hepcidin-induced cancer cell death is similar to the bactericidal effect of hepcidin against uropathogenic Escherichia coli (41). Many other ACPs have likewise been shown to cause substantial damage to the plasma membrane of cancer cells $(15,19-21)$. This mechanism of action contrasts with the ACP bovine lactoferricin, which has a minimal effect on cancer cell membrane integrity but rather enters the cancer cell and induces apoptosis and subsequent DNA fragmentation by targeting mitochondrial membranes (18). It is likely that hepcidin-induced DNA fragmentation is also the result of damage to the mitochondria and subsequent caspase activation that occurs after already lethal cell membrane damage has occurred. Given the severe damage to the 
A

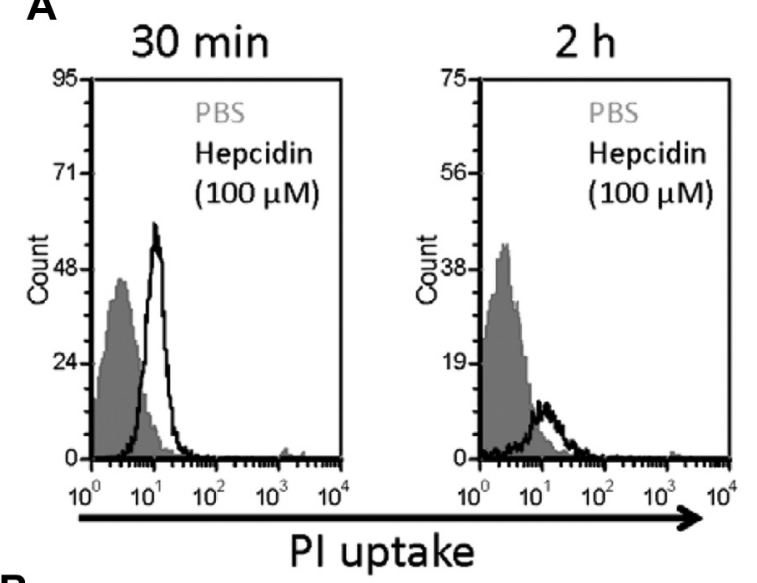

B

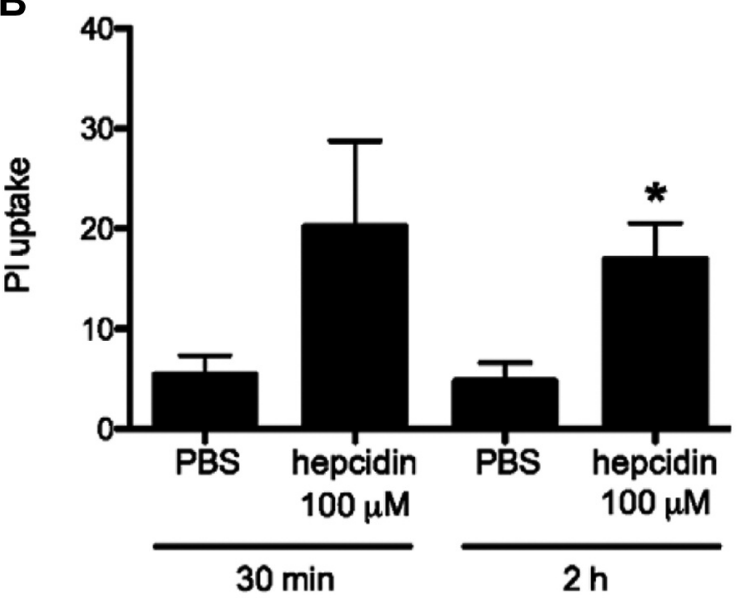

C
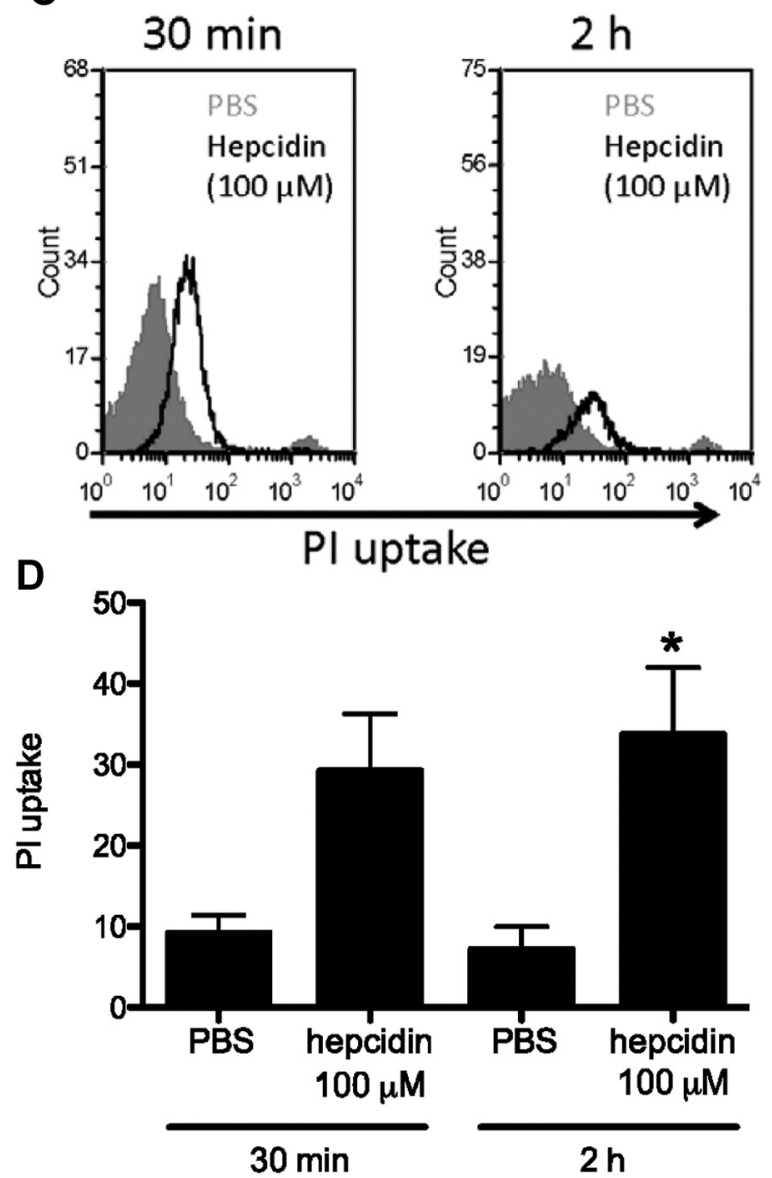

Figure 2. Human hepcidin causes time-dependent permeabilization of human and mouse myeloma cell plasma membrane. (A, B) Human U266 and (C, D) mouse HOPC myeloma cells were cultured in the presence of medium alone, vehicle (PBS) or $100 \mu M$ human hepcidin for 30 min or 2 h and then stained with PI and analyzed by flow cytometry. Representative flow cytometry plots are shown in $(A)$ and $(C)$. The average PI uptake (B and D), reflecting cell membrane permeabilization relative to medium control, is expressed \pm SEM, $n=3 ; * p<0.05$ determined by one-way ANOVA and Tukey post-test.

plasma membrane of myeloma cells after 30 min exposure to hepcidin, it follows that DNA fragmentation may be a secondary effect that does not substantially contribute to hepcidin-mediated cytotoxicity against myeloma cells.

Melphalan-resistance in myeloma cells is attributed to antioxidant defenses (42), as well as alterations in cell signaling and nuclear localization of survival-promoting nuclear factor-kB (NF-kB) and survivin (43). These mechanisms would be protective against programmed cell death, due to interference with the complex signaling processes that mediate apoptosis. However, hepcidin-induced myeloma cell death is initiated by extensive disruption of plasma membrane integrity, resulting in mechanical cell lysis that is equally toxic to melphalan-resistant and melphalannaïve myeloma cells. Other ACPs have also shown activity against chemoresistant cancer cells $(15,22,23)$, although the mechanism of action is not yet clear.
Preferential toxicity to myeloma cells compared to PC3 human prostate and HT-29 human colorectal cancer cells may be due to a greater concentration of negatively charged amino acids on the myeloma cell surface. For example, myeloma cells express high levels of CD38, which contains many negative amino acid residues (44). Myeloma stem cells are primitive slow-growing myeloma progenitor cells that are resistant to therapy and are thus believed to contribute to the incurable nature of plasma cells myeloma (45). However, because stem cells also bear a negative membrane charge (46), hepcidin and other ACPs may represent a promising therapeutic option for elimination of myeloma stem cells.

Hepcidin is best known as a regulator of iron metabolism (25). The ability of hepcidin to reduce iron levels in the inflammatory setting of cancer likely inhibits neoplastic cell growth (47). Manipulating iron transport decreases cancer 
A
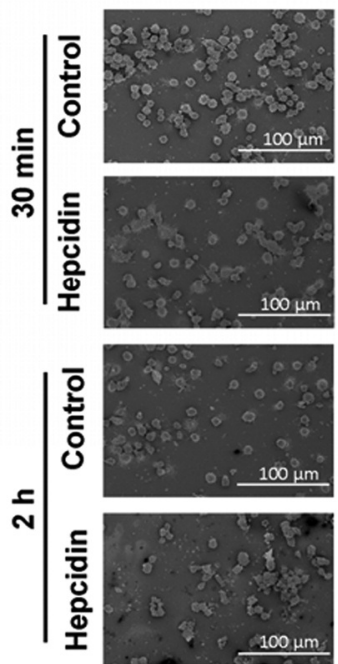
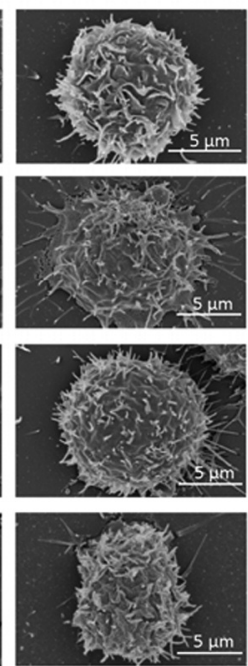
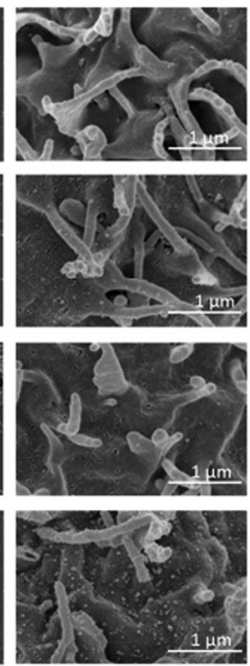

B
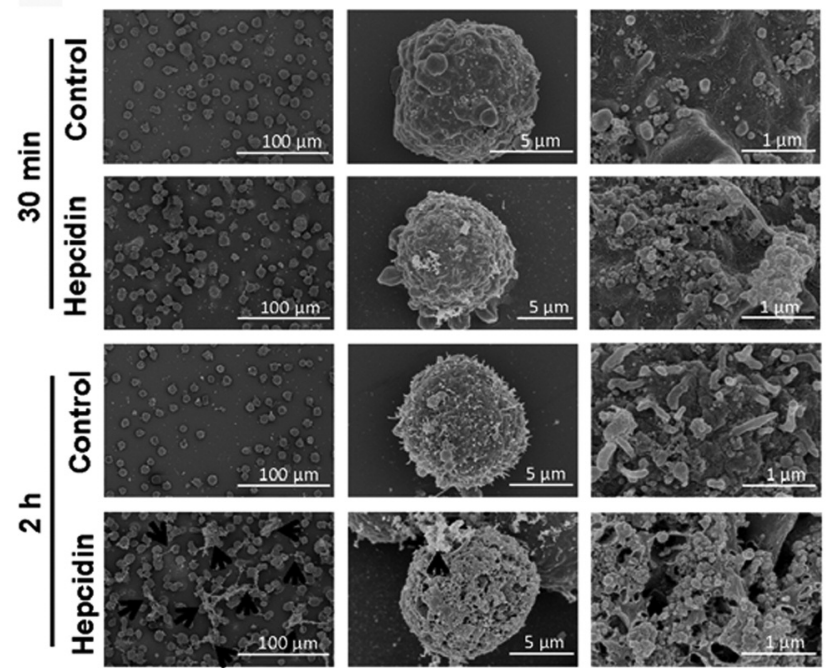

Figure 3. Human hepcidin causes pore formation in the plasma membrane of human and mouse myeloma cells. (A) U266 and (B) HOPC myeloma cells were cultured in the presence of vehicle (PBS) or $100 \mu M$ hepcidin. Cellular ultrastructure was visualized by scanning electron microscopy after 30 min and $2 \mathrm{~h}$ of culture. Black arrows indicate cellular fragments.

A

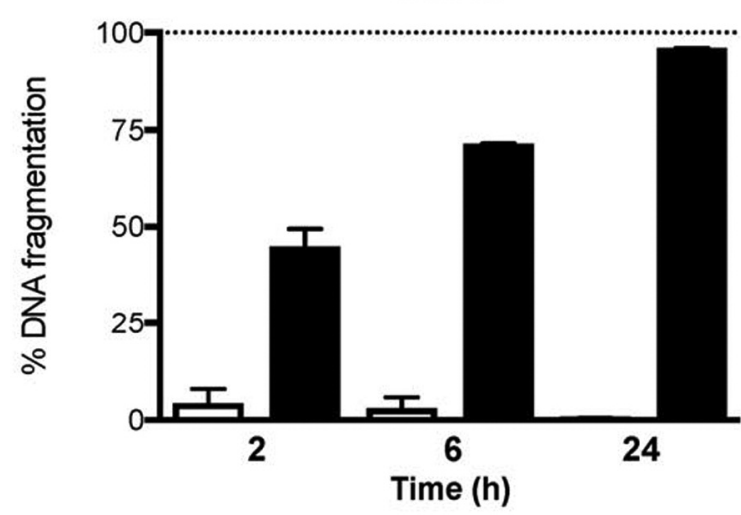

B

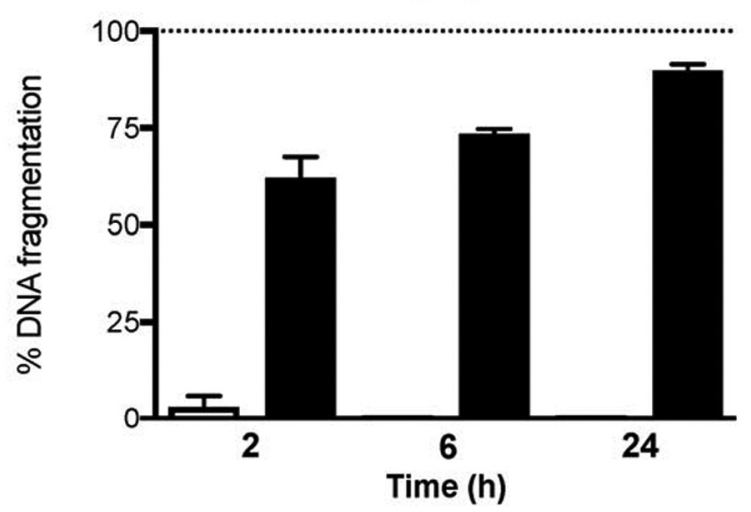

Control

Hepcidin

Figure 4. Human hepcidin induces DNA fragmentation in human and mouse myeloma cells. (A) HOPC and (B) U266 myeloma cells were cultured in the presence of vehicle (PBS) alone or $100 \mu \mathrm{M}$ hepcidin for 2, 6 or $24 \mathrm{~h}$. DNA fragmentation was then measured. Data are expressed as $\%$ DNA fragmentation $\pm S D$ in a representative experiment $(n=2)$.

cell growth (48). As our study exclusively made use of the 20-amino acid isoform of hepcidin that lacks the N-terminal iron regulatory domain (38), its cytotoxic effect on myeloma cells was de facto iron-independent. Our findings suggest that hepcidin may contribute to innate anticancer immunity, by virtue of its ability to interact with and disrupt negatively charged cancer cell membranes. The concentrations of hepcidin that were cytotoxic for myeloma cells are similarly reported for in vitro antimicrobial concentrations (41), both of which are higher than hepcidin levels measured in healthy individuals (49) and in individuals with plasma cell myeloma (23). Interestingly, in a lower $\mathrm{pH}$ environment the 
concentration of hepcidin required to kill bacteria is decreased (50). Acidic tumor microenvironments may therefore enhance the effectiveness of hepcidin-induced cell death, such that physiologic concentrations of hepcidin are lethal to cancer cells (51).

Our findings, taken together with the increased levels of hepcidin reported in the circulation of multiple myeloma patients (32), suggest that hepcidin is part of the innate immune response to this hematological malignancy. Hepcidin is induced in multiple myeloma by increased bone morphogenetic protein 2 and IL-6 (52), decreasing ferroportin expression and leading to anemia (53). Limiting iron availability is one potential way that hepcidin could limit myeloma growth, in addition to its direct cytotoxic activity. Effective treatment of multiple myeloma decreases the hepcidin levels in patients (54). Hepcidin may also contribute to innate immune response to other types of cancer since hepcidin levels are increased in colorectal cancer (55), breast cancer (56), lung cancer (57), and pancreatic cancer (58). This would explain the increased risk of cancer in individuals with hereditary hemochromatosis, thalassemia, and iron deficiency anemia, all of which are associated with reduced hepcidin expression. Hepcidin may therefore be a prognostic indicator for both hematological and nonhematological malignancies (56-58). Natural cancer defense has been observed in humans and other animals (59), including p53-dependent upregulation of hepcidin (60). However, additional study is required to fully understand the physiological role of hepcidin in multiple myeloma. Nevertheless, hepcidin warrants further investigation as a potential therapeutic for the treatment of multiple myeloma.

\section{Conflicts of Interest}

The Authors declare no conflicts of interest.

\section{Authors' Contributions}

D.C., A.H., R.L., D.H., and M.C.: Conception and study design; D.C., A.H., and M.C.: Collection of data; D.C., A.H., K.M., D.H., and M.C.: Analysis and interpretation of data; D.C., K.M., D.H., and M.C.: drafting of the article; and revision of the article. All Authors approved the final version of the article.

\section{Acknowledgements}

This research was funded by the Acadia University Research Fund (M.C.), the Breast Cancer Society of Canada (D.H.), the Canadian Cancer Society/Canadian Breast Cancer Foundation (D.H.), the Capital Health Research Fund (D.C.), the Michael Smith Foundation for Health Research (A.H.), the Natural Sciences and Engineering Research Council (A.H. and K.M.), Research Nova Scotia (K.M.), and the Raddall Fund (M.C.).

\section{References}

1 Committee CCSA: Canadian cancer statistics 2018. Toronto, ON, Canadian Cancer Society, 2018.

2 Hanbali A, Hassanein M, Rasheed W, Aljurf M and Alsharif F: The evolution of prognostic factors in multiple myeloma. Adv Hematol 2017, 2017. PMID: 28321258. DOI: 10.1155/2017/4812637

3 Lin HM, Davis KL, Kaye JA, Luptakova K, Nagar SP and Mohty M: Real-world treatment patterns, outcomes, and healthcare resource utilization in relapsed or refractory multiple myeloma: Evidence from a medical record review in France. Adv Hematol 2019: 4625787, 2019. PMID: 30838045. DOI: $10.1155 / 2019 / 4625787$

4 Martin T and Huff CA: Multiple myeloma: Current advances and future directions. Clin Lymphoma Myeloma Leuk 19: 255263, 2019. PMID: 31130488. DOI: 10.1016/j.clml.2019.03.025

5 Weers M de, Tai Y-T, Veer MS van der, Bakker JM, Vink T, Jacobs DCH, Oomen LA, Peipp M, Valerius T, Slootstra JW, Mutis T, Bleeker WK, Anderson KC, Lokhorst HM, Winkel JGJ van de and Parren PWHI: Daratumumab, a novel therapeutic human CD38 monoclonal antibody, induces killing of multiple myeloma and other hematological tumors. J Immunol 186: 18401848, 2011. PMID: 21187443. DOI: 10.4049/jimmunol.1003032

6 van der Veer MS, de Weers M, van Kessel B, Bakker JM, Wittebol S, Parren PWHI, Lokhorst HM and Mutis T: The therapeutic human CD38 antibody daratumumab improves the anti-myeloma effect of newly emerging multi-drug therapies. Blood Cancer J 1: e41, 2011. PMID: 22829073. DOI: 10.1038/bcj.2011.42

7 van der Veer MichaelS, de Weers M, van Kessel B, Bakker JM, Wittebol S, Parren PWHI, Lokhorst HM and Mutis T: Towards effective immunotherapy of myeloma: enhanced elimination of myeloma cells by combination of lenalidomide with the human CD38 monoclonal antibody daratumumab. Haematologica 96: 284290, 2011. PMID: 21109694. DOI: 10.3324/haematol.2010.030759

8 Wang G, Watson KM and Buckheit RW: Anti-human immunodeficiency virus type 1 activities of antimicrobial peptides derived from human and bovine cathelicidins. Antimicrob Agents Chemother 52: 3438-3440, 2008. PMID: 18591279. DOI: $10.1128 / A A C .00452-08$

9 Bergman P, Walter-Jallow L, Broliden K, Agerberth B and Söderlund J: The antimicrobial peptide LL-37 inhibits HIV-1 replication. Curr HIV Res 5: 410-415, 2007. PMID: 17627504. DOI: $10.2174 / 157016207781023947$

10 Couto J, Tonk M, Ferrolho J, Antunes S, Vilcinskas A, de la Fuente J, Domingos A and Cabezas-Cruz A: Antiplasmodial activity of tick defensins in a mouse model of malaria. Ticks Tick-Borne Dis 9: 844-849, 2018. PMID: 29567145. DOI: 10.1016/j.ttbdis.2018.03.011

11 Overhage J, Campisano A, Bains M, Torfs ECW, Rehm BHA and Hancock REW: Human host defense peptide LL-37 prevents bacterial biofilm formation. Infect Immun 76: 4176-4182, 2008. PMID: 18591225. DOI: 10.1128/IAI.00318-08

12 Boullet H, Bentot F, Hequet A, Ganem-Elbaz C, Bechara C, Pacreau E, Launay P, Sagan S, Jolivalt C, Lacombe C, Moumné $\mathrm{R}$ and Karoyan P: Small antimicrobial peptide with in vivo activity against sepsis. Mol Basel Switz 24, 2019. PMID: 31052373. DOI: $10.3390 /$ molecules 24091702

13 Hilchie AL, Wuerth K and Hancock REW: Immune modulation by multifaceted cationic host defense (antimicrobial) peptides. 
Nat Chem Biol 9: 761-768, 2013. PMID: 24231617. DOI: 10.1038/nchembio.1393

14 Hilchie AL, Conrad DM, Coombs MRP, Zemlak T, Doucette CD, Liwski RS and Hoskin DW: Pleurocidin-family cationic antimicrobial peptides mediate lysis of multiple myeloma cells and impair the growth of multiple myeloma xenografts. Leuk Lymphoma 54: 2255-2262, 2013. PMID: 23350892. DOI: $10.3109 / 10428194.2013 .770847$

15 Hilchie AL, Doucette CD, Pinto DM, Patrzykat A, Douglas S and Hoskin DW: Pleurocidin-family cationic antimicrobial peptides are cytolytic for breast carcinoma cells and prevent growth of tumor xenografts. Breast Cancer Res 13: R102, 2011. PMID: 22023734. DOI: 10.1186/bcr3043

16 Hilchie AL, Hoskin DW and Power Coombs MR: Anticancer activities of natural and synthetic peptides. Adv Exp Med Biol 1117: 131-147, 2019. PMID: 30980357. DOI: 10.1007/978-98113-3588-4_9

17 Hoskin DW and Ramamoorthy A: Studies on anticancer activities of antimicrobial peptides. Biochim Biophys Acta 1778: 357-375, 2008. PMID: 18078805. DOI: 10.1016/j.bbamem. 2007.11.008

18 Mader JS, Salsman J, Conrad DM and Hoskin DW: Bovine lactoferricin selectively induces apoptosis in human leukemia and carcinoma cell lines. Mol Cancer Ther 4: 612-624, 2005. PMID: 15827335. DOI: 10.1158/1535-7163.MCT-04-0077

19 Berge G, Eliassen LT, Camilio KA, Bartnes K, Sveinbjørnsson $\mathrm{B}$ and Rekdal O: Therapeutic vaccination against a murine lymphoma by intratumoral injection of a cationic anticancer peptide. Cancer Immunol Immunother 59: 1285-1294, 2010. PMID: 20422410. DOI: 10.1007/s00262-010-0857-6

20 Eike L-M, Yang N, Rekdal $\varnothing$ and Sveinbjørnsson B: The oncolytic peptide LTX-315 induces cell death and DAMP release by mitochondria distortion in human melanoma cells. Oncotarget 6: 34910-34923, 2015. PMID: 26472184. DOI: 10.18632/ oncotarget.5308

21 Hilchie AL, Sharon AJ, Haney EF, Hoskin DW, Bally MB, Franco OL, Corcoran JA and Hancock REW: Mastoparan is a membranolytic anti-cancer peptide that works synergistically with gemcitabine in a mouse model of mammary carcinoma. Biochim Biophys Acta - Biomembr 1858: 3195-3204, 2016. PMID: 27693190. DOI: 10.1016/j.bbamem.2016.09.021

22 Kim S, Kim SS, Bang YJ, Kim SJ and Lee BJ: In vitro activities of native and designed peptide antibiotics against drug sensitive and resistant tumor cell lines. Peptides 24: 945-953, 2003. PMID: 14499271. DOI: 10.1016/s0196-9781(03)00194-3

23 Johnstone SA, Gelmon K, Mayer LD, Hancock RE and Bally MB: In vitro characterization of the anticancer activity of membrane-active cationic peptides. I. Peptide-mediated cytotoxicity and peptide-enhanced cytotoxic activity of doxorubicin against wild-type and p-glycoprotein overexpressing tumor cell lines. Anticancer Drug Des 15: 151-160, 2000. PMID: 10901303.

24 Park $\mathrm{CH}$, Valore EV, Waring AJ and Ganz T: Hepcidin, a urinary antimicrobial peptide synthesized in the liver. J Biol Chem 276: 7806-7810, 2001. PMID: 11113131. DOI: 10.1074/jbc.M00 8922200

25 Singh B, Arora S, Agrawal P and Gupta SK: Hepcidin: A novel peptide hormone regulating iron metabolism. Clin Chim Acta 412: 823-830, 2011. PMID: 21333642. DOI: 10.1016/j.cca.2011. 02.014
26 Nemeth E, Tuttle MS, Powelson J, Vaughn MB, Donovan A, Ward DM, Ganz T and Kaplan J: Hepcidin regulates cellular iron efflux by binding to ferroportin and inducing its internalization. Science 306: 2090-2093, 2004. PMID: 15514116. DOI: 10.1126/science. 1104742

27 Kanamori Y, Murakami M, Matsui T and Funaba M: The regulation of hepcidin expression by serum treatment: requirements of the BMP response element and STAT- and AP1-binding sites. Gene 551: 119-126, 2014. PMID: 25151311. DOI: $10.1016 /$ j.gene.2014.08.037

28 Kanamori Y, Murakami M, Matsui T and Funaba M: JNK facilitates IL-1 $\beta$-induced hepcidin transcription via JunB activation. Cytokine 111: 295-302, 2018. PMID: 30269025. DOI: $10.1016 /$ j.cyto.2018.09.014

29 Wrighting DM and Andrews NC: Interleukin-6 induces hepcidin expression through STAT3. Blood 108: 3204-3209, 2006. PMID: 16835372. DOI: 10.1182/blood-2006-06-027631.

30 Kemna EHJM, Kartikasari AER, van Tits LJH, Pickkers P, Tjalsma $\mathrm{H}$ and Swinkels DW: Regulation of hepcidin: insights from biochemical analyses on human serum samples. Blood Cells Mol Dis 40: 339-346, 2008. PMID: 18023212. DOI: 10.1016/j.bcmd.2007.10.002

31 Weiss G, Ganz T and Goodnough LT: Anemia of inflammation. Blood 133: 40-50, 2019. PMID: 30401705. DOI: 10.1182/blood2018-06-856500

32 Victor M, Evgeniy H, Gergana T, Julia P, Vasil V, Borislav M, Ivo B, Zlatina $G$ and Kamen T: Serum hepcidin levels in multiple myeloma. Clin Lab 63: 1273-1277, 2017. PMID: 28792693. DOI: $10.7754 / C l i n . L a b .2017 .160637$

33 Sangkhae V and Nemeth E: Regulation of the iron homeostatic hormone hepcidin. Adv Nutr 8: 126-136, 2017. PMID: 28096133. DOI: $10.3945 /$ an.116.013961

34 Hodroj MH, Bou-Fakhredin R, Nour-Eldine W, Noureldine HA, Noureldine MHA and Taher AT: Thalassemia and malignancy: An emerging concern? Blood Rev 37: 100585, 2019. PMID: 31253373. DOI: $10.1016 /$ j.blre.2019.06.002

35 Elmberg M, Hultcrantz R, Ekbom A, Brandt L, Olsson S, Olsson R, Lindgren S, Lööf L, Stål P, Wallerstedt S, Almer S, SandbergGertzén $\mathrm{H}$ and Askling J: Cancer risk in patients with hereditary hemochromatosis and in their first-degree relatives. Gastroenterology 125: 1733-1741, 2003. PMID: 14724826. DOI: $10.1053 /$ j.gastro.2003.09.035

36 Lopez A, Cacoub P, Macdougall IC and Peyrin-Biroulet L: Iron deficiency anaemia. Lancet 387: 907-916, 2016. PMID: 26314490. DOI: 10.1016/S0140-6736(15)60865-0

37 Conrad DM, Hoskin DW, Liwski R and Naugler C: A reexamination of the role of the acute phase protein response in innate cancer defence. Med Hypotheses 93: 93-96, 2016. PMID: 27372864. DOI: 10.1016/j.mehy.2016.05.025

38 Nemeth $\mathrm{E}$ and Ganz T: The role of hepcidin in iron metabolism. Acta Haematol 122: 78-86, 2009. PMID: 19907144. DOI: $10.1159 / 000243791$

39 Hoskin DW, Butler JJ, Drapeau D, Haeryfar SMM and Blay J: Adenosine acts through an $\mathrm{A} 3$ receptor to prevent the induction of murine anti-CD3-activated killer T cells. Int J Cancer 99: 386395, 2002. PMID: 11992407. DOI: 10.1002/ijc. 10325

40 Esma F, Salvini M, Troia R, Boccadoro M, Larocca A and Pautasso C: Melphalan hydrochloride for the treatment of multiple myeloma. Expert Opin Pharmacother 18: 1127-1136, 2017. PMID: 28658983. DOI: 10.1080/14656566.2017.1349102 
41 Houamel D, Ducrot N, Lefebvre T, Daher R, Moulouel B, Sari M-A, Letteron P, Lyoumi S, Millot S, Tourret J, Bouvet O, Vaulont S, Vandewalle A, Denamur E, Puy H, Beaumont C, Gouya L and Karim Z: Hepcidin as a major component of renal antibacterial defenses against uropathogenic Escherichia coli. J Am Soc Nephrol 27: 835-846, 2016. PMID: 26293821. DOI: 10.1681/ASN.2014101035

42 Gourzones C, Bellanger C, Lamure S, Gadacha OK, De Paco EG, Vincent L, Cartron G, Klein B and Moreaux J: Antioxidant defenses confer resistance to high dose melphalan in multiple myeloma cells. Cancers 11, 2019. PMID: 30925767. DOI: 10.3390/cancers 11040439

43 Tsubaki M, Takeda T, Tomonari Y, Koumoto Y, Imano M, Satou $\mathrm{T}$ and Nishida S: Overexpression of HIF-1 $\alpha$ contributes to melphalan resistance in multiple myeloma cells by activation of ERK1/2, Akt, and NF-kB. Lab Invest 99: 72-84, 2019. DOI: 10.1038/s41374-018-0114-8

44 Lee HC: Structure and enzymatic functions of human CD38. Mol Med 12: 317-323, 2006. PMID: 17380198. DOI: 10.2119/2006-00086.Lee

45 Johnsen HE, Bøgsted M, Schmitz A, Bødker JS, El-Galaly TC, Johansen P, Valent P, Zojer N, Van Valckenborgh E, Vanderkerken K, van Duin M, Sonneveld P, Perez-Andres M, Orfao A and Dybkær K: The myeloma stem cell concept, revisited: from phenomenology to operational terms. Haematologica 101: 1451-1459, 2016. PMID: 27903712. DOI: 10.3324/haematol.2015.138826

46 Kim DY, Kwon JS, Lee JH, Jin LM, Kim JH and Kim MS: Effects of the surface charge of stem cell membranes and DNA/polyethyleneimine nanocomplexes on gene transfection efficiency. J Biomed Nanotechnol 11: 522-530, 2015. PMID: 26307834. DOI: $10.1166 /$ jbn.2015.2060

47 Pfeifhofer-Obermair C, Tymoszuk P, Petzer V, Weiss G and Nairz M: Iron in the tumor microenvironment-connecting the dots. Front Oncol 8, 2018. PMID: 30534534. DOI: 10.3389/fonc. 2018.00549

48 Jiang XP, Elliott RL and Head JF: Manipulation of iron transporter genes results in the suppression of human and mouse mammary adenocarcinomas. Anticancer Res 30: 759-765, 2010. PMID: 20392994. DOI: 0250-7005/2010

49 Roe MA, Collings R, Dainty JR, Swinkels DW and FairweatherTait SJ: Plasma hepcidin concentrations significantly predict interindividual variation in iron absorption in healthy men. Am J Clin Nutr 89: 1088-1091, 2009. PMID: 19211819. DOI: 10.3945/ajen.2008.27297

50 Maisetta G, Petruzzelli R, Brancatisano FL, Esin S, Vitali A, Campa $\mathrm{M}$ and Batoni G: Antimicrobial activity of human hepcidin 20 and 25 against clinically relevant bacterial strains: effect of copper and acidic pH. Peptides 31: 1995-2002, 2010. PMID: 20713108. DOI: 10.1016/j.peptides.2010.08.007
51 Boedtkjer E and Pedersen SF: The acidic tumor microenvironment as a driver of cancer. Annu Rev Physiol 82: 103-126, 2020. PMID: 31730395. DOI: 10.1146/annurev-physiol-021119-034627

52 Maes K, Nemeth E, Roodman GD, Huston A, Esteve F, Freytes C, Callander N, Katodritou E, Tussing-Humphreys L, Rivera S, Vanderkerken K, Lichtenstein A and Ganz T: In anemia of multiple myeloma, hepcidin is induced by increased bone morphogenetic protein 2. Blood 116: 3635-3644, 2010. PMID: 20679527. DOI: 10.1182/blood-2010-03-274571

53 VanderWall K, Daniels-Wells TR, Penichet M and Lichtenstein A: Iron in multiple myeloma. Crit Rev Oncog 18: 449-461, 2013. PMID: 23879589. DOI: 10.1615/critrevoncog.2013007934

54 Katodritou E, Ganz T, Terpos E, Verrou E, Olbina G, Gastari V, Hadjiaggelidou C, Varthaliti M, Georgiadou S, Westerman M and Zervas K: Sequential evaluation of serum hepcidin in anemic myeloma patients: study of correlations with myeloma treatment, disease variables, and anemia response. Am J Hematol 84: 524-526, 2009. PMID: 19536845. DOI: 10.1002/ajh. 21448

55 Ward DG, Roberts K, Brookes MJ, Joy H, Martin A, Ismail T, Spychal R, Iqbal T and Tselepis C: Increased hepcidin expression in colorectal carcinogenesis. World J Gastroenterol WJG 14: 1339, 2008. PMID: 18322945. DOI: 10.3748/wjg.14.1339

56 Shao X, Cao F and Tao M: The clinical value of hepcidin in breast cancer and its bone metastasis. Ann Clin Lab Sci 47: 120128, 2017. PMID: 28442512. DOI: 0091-7370/17/0200-120

57 Chen Q, Wang L, Ma Y, Wu X, Jin L and Yu F: Increased hepcidin expression in non-small cell lung cancer tissue and serum is associated with clinical stage. Thorac Cancer 5: 14, 2014. PMID: 26766967. DOI: 10.1111/1759-7714.12046

58 Toshiyama R, Konno M, Eguchi H, Asai A, Noda T, Koseki J, Asukai K, Ohashi T, Matsushita K, Iwagami Y, Yamada D, Asaoka T, Wada H, Kawamoto K, Gotoh K, Kudo T, Satoh T, Doki Y, Mori $\mathrm{M}$ and Ishii H: Association of iron metabolic enzyme hepcidin expression levels with the prognosis of patients with pancreatic cancer. Oncol Lett 15: 8125, 2018. PMID: 29731920. DOI: 10.3892/ol.2018.8357

59 Jakóbisiak M, Lasek W and Gołab J: Natural mechanisms protecting against cancer. Immunol Lett 90: 103-122, 2003. PMID: 14687712. DOI: 10.1016/j.imlet.2003.08.005

60 Weizer-Stern O, Adamsky K, Margalit O, Ashur-Fabian O, Givol $\mathrm{D}$, Amariglio $\mathrm{N}$ and Rechavi G: Hepcidin, a key regulator of iron metabolism, is transcriptionally activated by $\mathrm{p} 53$. Br J Haematol 138: 253-262, 2007. PMID: 17593032. DOI: $10.1111 /$ j.1365-2141.2007.06638.x

Received October 31, 2020

Revised January 4, 2021

Accepted January 7, 2021 